\title{
Capital Adequacy Behavior: Empirical Evidence from Banking Sector of Pakistan
}

\author{
Sardar Muhammad Zahid ${ }^{1,2}$, Mehtab Anwar $^{3}$, Imtiaz Aqdas ${ }^{3} \&$ Muhammad Usman Goraya ${ }^{3}$ \\ ${ }^{1}$ Upper Great Plains Transportation Institute, North Dakota State University, Fargo, USA \\ ${ }^{2}$ Department of Management Sciences, COMSATS Institute of Information Technology, Islamabad, Pakistan \\ ${ }^{3}$ Al-Khair University, AJK, Pakistan \\ Correspondence: Sardar Muhammad Zahid, Upper Great Plains Transportation Institute, North Dakota State \\ University, Fargo, USA \& Department of Management Sciences COMSATS Institute of Information \\ Technology Islamabad, Pakistan. E-mail: drsardarzahid@gmail.com
}

Received: June 5, 2015

doi:10.5539/ijef.v7n9p96
Accepted: June 30, 2015

Online Published: August 25, 2015

URL: http://dx.doi.org/10.5539/ijef.v7n9p96

\begin{abstract}
The study applied fixed effect panel estimation analysis to investigate into capital adequacy behavior of banking industry of Pakistan over the period 2004 to 2009, under numerous regulatory stresses particularly when there is contemporary global crisis embryonic around the world. The emphasis in this paper will be to explore exactly how institutions react to the regulatory capital requirements changes. We found a positive and statistically significant association between return on assets and capital ratio. This pertains to the fact that in order to upturn capital, banks depends more on retained earnings. Another important finding of this study is that the certain features of the bank serves as significantly important factors for a bank response to changing capital requirement such as size (SIZE) has a statistically significant and a negative effect on capital, means that bigger banks are less inclined towards increasing capital as compare to small banks. A likely elucidation for this can be that big banks have easy and better access to the bond market. The relation between risk weighted capital ratio and regulatory pressure is positive and significant, as it implies that banks under regulatory pressure will prefer into less risky ventures. This in turn reduces the chances of bank failure and failure of speculative activities thus reducing the social and economic costs arising from such failures.
\end{abstract}

Keywords: capital adequacy, capital ratio, regulatory pressures, Pakistan, banks, fixed effect

\section{Introduction}

Due to the significant part in the payment arrangement and credit facilitation and economic development, one of the most heavily regulated industries is the banking industry. Capital regulation plays a vital role in banks oversight, and dictates these firms to keep a significant sum of capital as cushion to counter unforeseen losses or hostile shockwaves that may result in bank catastrophe. The extensive hitches that have astounded the banking industry in recent times have upstretched a lot of questions about the capital requirement design and capital level in the system. As a consequence, supervisory bodies are rethinking a more essential approach to govern capital requirements, which are playing an important role in changing behavior and risk perception of banks. According to Richardson and Stephenson (2002), there is a need of quick actions to address numerous eminent market failures, that have may be a significant threat to market confidence and financial stability. The difficulties comprise of universal risks and unwanted externalities that originate from bank disasters, as well as information lopsidedness between bank management and depositors that have a dire effect on the financial health of the banks. So authorities are continuously been stressed up with excessive risk taking. Over the course of history, predominantly after the financial crises, the effectiveness of regulatory procedures as, capital adequacy behavior, moral standardization, introduction of certain regulatory procedures and operational measures gains much attention. The focus in this study will be to explore the effects of regulatory measures on the capital adequacy behaviors of the banks.

According to Goodhart (2008), the seven fields of regulatory concern are the bank liquidation regime, the deposit insurance, the money market operations by central bank, crisis management, insolvency risk management, Procyclicality in CARs, general lack of counter-cyclical instruments, and reputational risk. 
Typically the market failure gives the explanation for any regulation or directive, such as market supremacy or asymmetry of information among buyers and sellers. Up till now there is no consensus on either the banks must be evaluated or regulated, but if there is a need to do so, then how they should be synchronized. To a certain extent this shows the lack of agreement on the tip of bazaar failure that does not consider unrestricted banking as finest. However, the explanations that are frequently given for regulating banks are the risk of a systemic catastrophe and the powerlessness of depositors to monitor banks.

Universal economic crisis has influenced the developing countries relying on the configuration of regional economies and their assimilation into world markets. According to a World Bank analysis, all through the developing world development is predicted to slow down in 2009, as a consequence of declining exports and remittances, and stock market abatement caused by capital flight and depreciating local currencies, but still recession is not expected. Yet, the turnaround of the rise in fuel and food prices is changing terms of trade and serving to relieve inflationary pressures.

Moreover, weak institutional grounds and the incapability of consecutive governments to embark on long-term and broad-based rectifications, reforms and policies have made continuous financial growth complex. Hence, Pakistan's economy was constantly in a horrible form well before the existing economic crisis stroked the developed countries. It is said that, as the Pakistan's economic or financial sector is quite weak in nature and is not tightly embedded to the international financial sector, so it can survive the existing international crisis. However in the long run the nation will have to face the impacts of the catastrophe on several counts such as declining foreign direct investment, development assistance, remittances and exports. Furthermore, the twin deficit, budgetary and trade aspects, the thrust in stock markets, power shortages and increasing food inflation were very slightly connected with the international economic crisis. Political unsteadiness and deprived law and order condition have taken a charge on Pakistan's economy, whilst the international economic crisis supplement considerable descending pressures on its economic markets.

\subsection{Banking Sector and Pakistan}

Banking in Pakistan was taken up by branches of British banks before the separation in 1947. The central bank i.e. the State Bank of Pakistan was formed after partition in 1948. It understood the managerial and economic policy supremacy of the State Bank of India. A number of specialized development finance institutions (DFIs) such as Agricultural Development Bank (ADB) and Industrial Development Bank of Pakistan (IDBP) emerged in the period of $60 \mathrm{~s}$ to $70 \mathrm{~s}$. These DFIs were intended to concentrate on specific priority sector lending either controlled directly through the SBP or by the state. Government nationalized all domestic commercial banks in 1974. With limited supervisory powers. The Pakistan Banking Council (PBC), was established which assumed the role of a banking holding company. However, in 1997 PBC was dissolved, and the sole regulatory authority for banks and financial institutions rest with the State Bank of Pakistan (SBP).

\subsection{The Determinants of Capital}

Diamond and Rajan (2000), hypothetically develop the decisions of banks to invest in most favorable capital arrangement. Holding higher amounts of capital lessens the likelihood of economic distress. On contrast protecting on capital holdings decreases liquidity formation and therefore profitability. The current practice disclosed that banks are maintaining capital levels well beyond the minimum requirement from regulators, capital ratios have enlarged significantly in the past decade (Berger et al., 1995; Flannery, 2007). In United States banks grasp levels of capital greater than the bare minimum obligation by about seventy five percent. Figuring out this rational, that the choice of banks regarding most favorable that market forces determines the capital ratio, instead of regulatory compulsions. Likewise, Ashcraft (2004), does not locate regulatory necessities to compel capital arrangement decisions of banks. In these lines a study by Gropp and Heider (2010), evidenced that regulation is the second order effect for banks to conclude their capital for great United States and European banks. They demonstrate that banks capital arrangement demonstrates a mirror to those of nonfinancial organizations. One more thread of literature comes up with the proof that it is primary implied cost to regulation that forces the decisions of banks to grasp capital buffers. Buser, Chen, and Kane (1981), states that regulatory disincentives to risk taking of banks should surpass the conversation on banks most favorable capital. Instead of those allowing banks to tire out their contract value, the supervisory body should implement liquidation of the bank. To prevent interference of the regulators banks must grasp capital buffers enough beyond the regulatory minimum, the banks risk captivating incentives exclusively rely upon this buffer and not on the full level of capital. Homogenous with the literature signifying that regulation is a second order effect to the decision of bank on capital, discover that the capital obligations forced by the regulator has no more run effect on banks risk captivating. 


\subsection{Capital Requirements and Bank Behavior}

From too long it is recommended that regulations of bank relieve troubles starting since the division of ownership from administration, and to decrease ethical peril in banks (Dewatripont \& Tirole, 1994; Hellmann, et al., 2000). The literature advances regulations to alleviate the falsifications that occur from insufficient shifting of risk because of inappropriately priced deposit insurance. Devoid of right regulation, small charter value banks may have an inducement toward disproportionate risks (Furlong \& Keeley, 1989). Likewise, admittance toward safety net through deposit cover may maneuver the decision of bank on the most favorable arrangement of capital (Kareken \& Wallace, 1978; Merton, 1968). The risk bearing of banks may turn out to be insufficient. Captivating superior risks, that is lessening capital comparative to assets or rising asset danger could result in superior anticipated deposit cover subsidy or capital assumed from depositors than a failure in charter value, with the motivations of the savers to interfuse market regulation being condensed (Bhattacharya, Boot, \& Thakor, 1998), banks look a tradeoff in keeping superior capital ratios and producing better profits with more risk exposure. In locating superior capital supplies Furlong and Keeley (1989), discover incentives of banks to augment asset risk to be condensed. Capital necessities decrease moral hazard and hence alleviate deformities of the deposit insurance. On the other hand, as capital necessities limit the risk arrival, the incentives of the banks towards spending in project that have more risk may also increase (Kim \& Santomero, 1988).

The experiential proof on the connection between capital and risk propose that the decision of bank on capital structure are determined by defensive reasons such as cost attached to bankruptcy, regulatory cost, inadvertent impacts of minimum capital principles and supremacy of leverage. Instead of inducements for exploiting the deposit insurance financial support (Jacques \& Nigro, 1997; Rime, 2001; Shrieves \& Dahl, 1992). In exercising a concurrent equations structure, Shrieves and Dahl (1992), discover an optimistic association among risk acknowledgements and capital levels. According to Rime (2001), the Swiss banks which are near the minimum capital obligation regulate their capital standards upwards. According to Shim (2010), the externalities of capital guidelines have a constructive impact on insurers to bear risk. The capital directives can enhance capital sufficiency of undercapitalized insurers. Until now the experiential literature on banks' risk captivating incentives discover defensive motives to dictate banks capital decisions.

Early investigation into information showed that a few authors had previously provided experimental data by a lot of articles regarding capital sufficiency. For example it was extremely astonishing to discover that Shrieves and Dahl (1992), had previously created a model called "Simultaneous Equation Model" in 1992 for measuring capital sufficiency of banks from a dogmatic viewpoint. Afterwards a lot of authors have chased Shrieves and Dahl (1992), to build up sensible experimental proof on the topic. For example: Bertrand (2001), imitated the model with a few obligatory alterations.

\section{Methodology}

Since the purpose of this paper is to study the capital adequacy behavior of commercial banks in Pakistan, quantitative method of conducting research is used by using appropriate statistical tests to understand the disposition and consequences of independent variables on capital ratio.

\subsection{Sample}

For the purpose of this study data from individual commercial banks during the time period of 2004-09 is used for the study. The aim of the paper is to perform an analysis on the basis of the accounting measures incorporated by the commercial banks. Information regarding these measures will be collected through secondary data sources such as the income statement and balance sheet that is a part of the bank's annual report. In Pakistan, as per law, each of the listed banks is required to announce or make available a copy of their annual report at the end of each financial year. Due to the objective nature of business among other things, special purpose banks are eliminated from the sample and only public limited commercial banks will be incorporated.

\subsection{Model Specification and Definition Variable}

$$
\text { CapitalRatio }_{i, t}=\alpha_{i}++\beta_{1} R_{0} O A_{i, t}+\beta_{2} \text { RISK }_{i, t}+\beta_{3} L_{R I S K} K_{i, t}+\beta_{4} S I Z E_{i, t}+\beta_{5} C_{L L} L_{i, t}+\beta_{6} R E G_{i, t}+\varepsilon_{i, t}
$$

The fixed effect regression model is a panel estimation technique employed here to determine the cause and effect relationship existing between the dependent and independent variable. In order to decide which among the two models is the most effective for the study the Hausman test was used. The null hypothesis for the test is that all $\alpha_{\mathrm{i}}$ are equal. It was established that a significant value of the Hausman test statistic indicates that the most appropriate model is the fixed effect model. Therefore we used fixed effect model in our study by using EView-6 software.

\section{a. Capital Ratio}


In Financial institutions' capital is divided into three classes as economic capital, actual or physical capital, and regulatory capital. Physical capital or actual capital is comprised of long term borrowings and equity. It is a ratio of equity to total assets also called capital ratio. Our dependent variable, the total risk-based capital ratio (RWCR), is calculated as the ratio of total regulatory capital (the sum of eligible tier 1, tier 2 and, where applicable, tier 3 capital) to total risk weighted assets in the banking and trading book.

\section{b. Risk}

Since risk assumes different natures in different industry settings, there is no fixed way to define the term. From the banking perspective risk is referred to a propensity of change in the value of certain assets. The absence of a universal way to calculate risk till now has forced the researchers to develop different ways to manage risk calculations. Hence for this study an accounting based approach would be used to estimate risk that uses accounting ratios to approximate signs of risky behavior. Such measure use ratio of loan loss reserves as a fraction of total assets to imitate credit risk. The advantage of this method is that it reveals banks risk taking tendencies over time, as provision of loan loss changes.

\section{c. Size}

The size in the equation is calculated as the natural log of total balance sheet. It is revealed as "SIZE" in the model offered above.

\section{d. Current Profits (ROA)}

To adjust capital ratios to avoid regulatory punishment, banks may have propensity to use retained earnings in the hours of complexity. As assembling equity capital in open market can seriously hurt an institution reputation, this argument is quite reasonable in a situation of distress, Therefore, ROA (return on asset) would be incorporated in the equation for investigation reasons. In the above model "ROA" demonstrates the current profits as a descriptive variable.

\section{e. Current Loan Losses (CLL)}

Level of capital is directly affected by the loan losses; the larger loan losses may leave banks in insolvency conditions, which might results in capital ratio declines. To investigate the special effects of loan losses they are approximated with new loan loss reserves. In the above model for measuring existing loan losses' influence on capital adequacy "CLL" is used as an expounding variable.

\section{f. Regulatory Pressure (REG)}

To ascertain whether the bank follows suite to the authoritarian guidelines, regulatory pressure would be judged. "Absolute capital buffer" is a term generally used to represent least amount of regulatory capital. To calculate the difficulty of following regulation for the financial organization regulatory pressure would be incorporated in the equation. The difference between regulatory minimum capital and solvency ratio would be taken to measure the regulatory pressure. If regulatory minimum capital is greater than the solvency ratio (i.e. 10\% from SBP) the variation would be included, otherwise zero would be incorporated in equation to show the influence of regulatory pressure. In the model regulatory pressure is represented by the "REG" descriptive variable.

\section{Results and Analysis}

\subsection{Descriptive Analysis}

The descriptive analysis is used to understand and explain the integrity of the variables that have been observed over six (6) years and across twenty six (26) banks.

Table 1. Descriptive analysis of variables

\begin{tabular}{lccccc}
\hline Variables & Mean & Maximum & Minimum & Std.Dev & Observations \\
\hline CAR & 15.44 & 61.83 & 0.010 & 10.34 & 156 \\
SIZE & 7.51 & 8.97 & 0.01 & 1.84 & 156 \\
ROA & 0.55 & 3.72 & -7.74 & 2.06 & 156 \\
RISK & 0.01 & 0.10 & 0.00 & 0.01 & 156 \\
REG & 0.76 & 1.00 & 0.00 & 0.43 & 156 \\
CLL & 11.68 & 16.77 & -4.60 & 0.43 & 156 \\
\hline
\end{tabular}

The purpose of calculating standard deviation is to project the integrity of the variables and the data. A smaller 
value of standard deviation translates a close connection between the consecutive variables. In retrospect large values of standard deviation show that data is widely distributed. Lower values of standard deviation in this study indicate that data is less scattered.
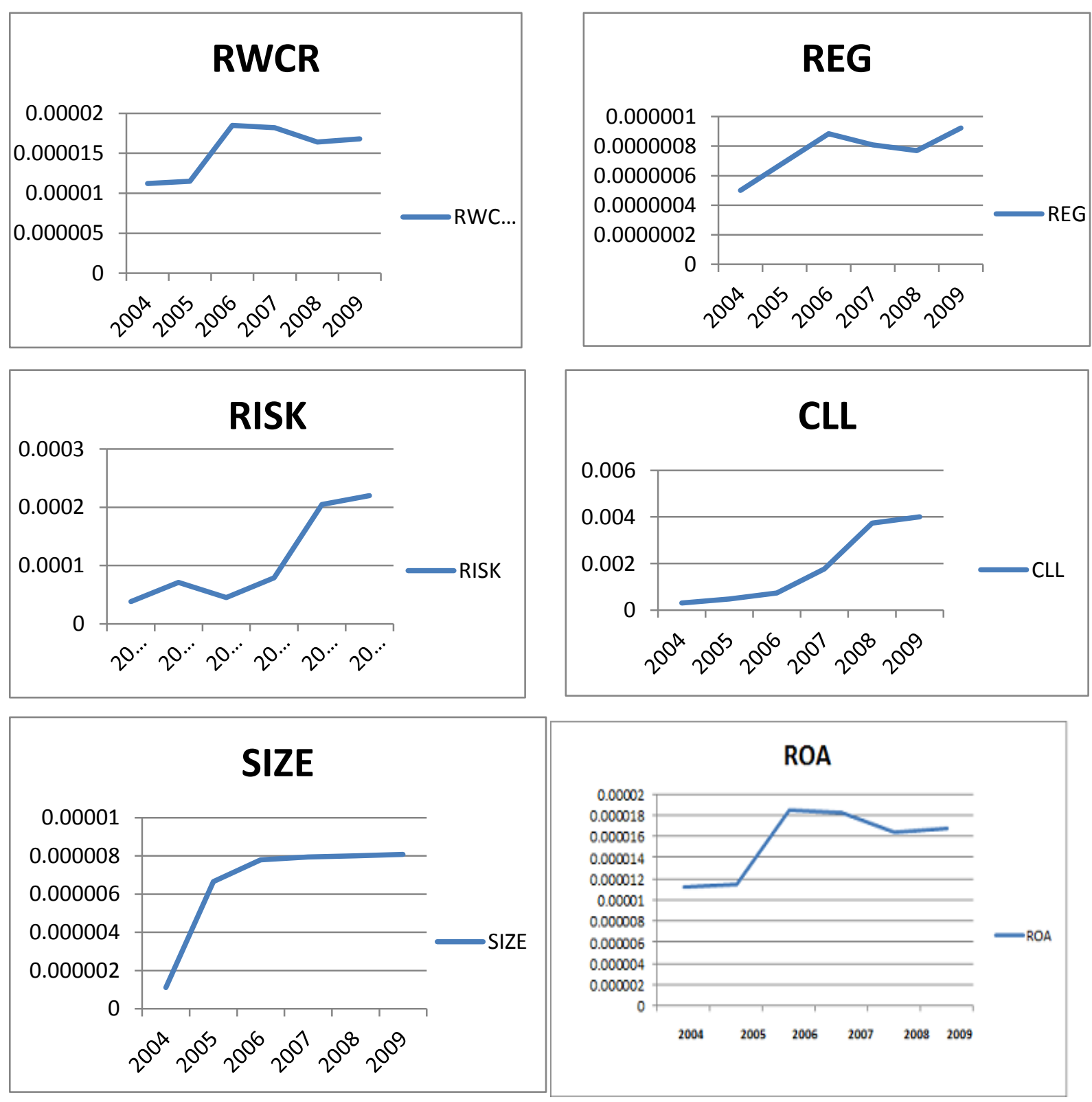

Figure 1. Graphs from mean values, risk weighted capital ratio and explanatory variables

It can be inferred from the Figures-1 that the means of the variables are very much in support of our hypothesis. The linear graphs based on the means of the variables clearly depict the desired trends of the variables. Figure 1, shows the trends of variable changes over the period from 2004-9. These figures provide significant information on how the banking industry of Pakistan behaved in response to credit crisis during that period. It can be seen in the graphs that in response to the crises ROA showed a decline in 2007. However, by the end of 2008 profitability tends to rise again. Capital ratios showed a similar trend, declining at the time of crisis but then slowly rising as a result of stable profits. An impressive outcome deciphered from the SIZE graph is the fact that the banking industry of Pakistan has shown a continuous trend of expansion and growth despite the depression prevalent in the market. A comparison of the RWCR and SIZE graphs shows the presence of a negative relationship between the two, supporting the hypothesis that size of banks and capital ratio are inversely related. 
Similarly it can be seen that RWCR and ROA have a positive relationship albeit the small proportion of the relation, a big difference in ROA causes a relatively small difference in capital behavior of banks. The relationship implies that banks with higher return on assets tend to have self-sufficiency on capital requirements as they can arrange to increase their capital ratio from within the company. It can also be deduced that risk and current loan losses of the banks show a clear increasing trend after 2007 that supports the fact that in the wake of global crisis the banks have been under severe pressure for loan defaults.

\subsection{Correlation Analysis}

The correlation analysis is done to reveal the association among the related variables along with their direction.

Table 2. Correlations

\begin{tabular}{lcccccc}
\hline & RWCR & RISK & SIZE & ROA & CLL & REG \\
\hline RWCR & 1 & & & & & \\
RISK & -0.14 & 1 & & & & \\
SIZE & 0.18 & 0.04 & 1 & & & \\
ROA & 0.10 & -0.61 & 0.17 & 1 & & \\
CLL & -0.01 & 0.29 & 0.85 & 0.07 & 1 & \\
REG & 0.48 & -0.16 & 0.35 & 0.13 & 0.24 & 1 \\
\hline
\end{tabular}

There is a positive correlation of 0.10 between RWCR and ROA that shows that profitability of the banks has a significant impact on the capital of the banks. Risk weighted capital ratio and size reveal a significant positive correlation of 0.18. That supports the empirical evidence that large banks tend to have higher risk weighted capital ratios as compared to smaller banks. There is a negative correlation between CLL and RWCR with a figure of -0.014. In retrospect the correlation between the risks weighted capital ratio and regulatory pressure is positively skewed valued at 0.48 , further strengthening the main hypothesis that as the regulatory pressure increases on banks they tend to have a higher ratio of capital to risk weighted assets.

Besides the correlation between dependent and independent variable, relationship between independent variables is also important as it reveals critical information about industry practices. The results of correlations suggest that bigger banks tend to take greater risks as opposed to smaller banks. Also, bigger banks tend to suffer greater loan losses.

The negative correlation between risk and regulatory pressure seems to be a good sign from a social perspective as it implies that banks under regulatory pressure will prefer into less risky ventures. This in turn reduces the chances of bank failure and failure of speculative activities thus reducing the social and economic costs arising from such failures.

\subsection{Results from Regression Analysis}

The fixed effect estimation technique on panel data with cross section weights was used. The results of regression model are given in table-3, which verifies that almost all the variables are significant and have the expected sign. Hence, it can be seen that the return on assets ROA has a statistically significant and positive effect having coefficient (2.36) on Risk weighted capital ratio. This pertains to the fact that banks seem to rely strongly on retained earnings in order to increase capital. It also shows that profitability has significant importance on capital of the banks. Loan losses (CLL), on the other hand show an expected significant and negative effect with coefficient (-0.85) on Risk weighted capital ratio. The relation between risk weighted capital ratio and regulatory pressure is significant and positive with coefficient value of (2.45) and is significant at 5\% that reaffirms the main hypothesis, as it implies that banks under regulatory pressure will prefer into less risky ventures. This in turn reduces the chances of bank failure and failure of speculative activities thus reducing the social and economic costs arising from such failures.

The parameter estimate of Risk is statistically significant at the $10 \%$ level, and positively associated with capital ratios. This means that banks increase capital when risk increases. The preceding result is consistent with the inference that the banks reply to escalations in risk, further suggesting that, at least under Basel accord and their guidelines, that banks in Pakistan are responsive to changing risk profiles. This outcome is erratic with moral hazard behavior, mean that with perception of risky asset portfolio banks tends to hold higher capital ratios.

The variable size (SIZE) is negatively and highly significant, which mean that large banks are experiencing 
greater economies of scale along with better at diversification. Which mean that big banks tends to have lower capital ratio, since in the event of difficulty they are expecting to be bail out. On the other hand, this type association may also reflect our sample, which is made up of moderately small banks, those have higher capital ratios. Additionally banks have the option to change not only the capital (numerator) but can change risk-weighted assets (denominator). Nevertheless this option, may result in a taking out of credit, mean that alterations in capital requirements may have macroeconomic significances.

Table 3. Fixed effect regression analysis

\begin{tabular}{lccc}
\hline Dependent Variable: Capital Ratio & & & p-Value \\
\hline Independent Variables & Coefficient & t-Statistics & $0.0003^{*}$ \\
Intercept & -19.77 & -3.69 & $0.0853^{* * *}$ \\
RISK & 32.93 & 1.74 & $0.0000^{*}$ \\
SIZE & -5.39 & -6.24 & $0.0020^{*}$ \\
ROA & 2.36 & 3.16 & $0.0201^{*}$ \\
CLL & -0.85 & -2.36 & $0.0312^{* *}$ \\
REG & 2.45 & 2.18 & \\
\hline Adjusted $\mathrm{R}^{2}$ & 0.71 & & \\
F- Statistics & 11.93 & & \\
Durbin Watson Statistics & 1.92 & &
\end{tabular}

The adjusted R- square is $0.71(71 \%)$ and F-statistics clearly shows the overall fitness of model. Moreover, the fixed effect regression with cross section weights tends to produce more reliable and applicable results as it takes into account the heterogeneity of individual firm in addition to the heteroskedasticity problem. Hence, the results of fixed effect with cross section weights are recommended to academician and corporate finance managers.

\section{Conclusion}

In our empirical analysis it may be ascertained that despite the distress in the market an overall increase in assets has been significant throughout the time line of analysis. Our results are consistent with the findings of Berger \& Bouwman, (2010) in that higher capital ratio and higher return are associated positively. The results have been proved and verified by using three different statistical methods. First by presenting a descriptive statistics together with the graphs that shows similar increasing trends of return on assets and capital ratio. Second, there has been a positive correlation between the return on assets and capital ratio. Third, the results are further verified by running the regression model (fixe effect panel technique).

Normally the cause of financial difficulty can be traced back to excessive optimism, where banks and other credit institutions focus more on future earnings rather than expected risks associated with such optimistic opportunities. It is therefore, crucial to have a minimum capital ratio to survive in a hostile environment of distress (Mehran \& Thakor, 2011).

It can be seen that there is a sheer decline in capital ratio, return on assets and other profitability measure discussed in analysis section as shown in the figure 1. In addition, with the help of various statistical measures we have established that our hypothesis: "large banks tend to have lower capital ratios" is consistent not only with our own empirical results but with the results of existing empirical research as well. Return on Assets has positive impact on the capital ratio of the banks. Our second hypothesis is also supported by the empirical findings that banks with higher capital ratio tend to have higher returns. This can be explained in terms of profitability as well, banks having positive profitability tend to have higher capital ratios as it provides internal sources of funds when needed. Both sides of the picture are relevant as far as the scope of our analysis is concerned. Regulatory pressure also plays a vital role in determining capital adequacy behavior of the banks as it has been revealed by the analysis section that there is a positive correlation between capital ratio and regulatory pressure, and also by panel estimation (fixe effect model) that it is positive and highly significant .In other words banks tend to increase their capital ratio in response to or under the burden of regulatory pressure.

Results have been shown in graphs, correlations and regression analysis that the risk and current loan loss variables show that risks increase during crisis periods. It is also interesting to note that larger banks tend to take more risk which is unhealthy from both social cost and economic point of view. This particular analysis opens a number of new research, for example a study of dynamic adjustments of capital from regulatory point of view is 
an interesting phenomenon that is yet to be explored. Another potential topic from the same regulatory point of view can be the time horizon of such regulatory adjustments by different banks and even among different economic systems.

\section{References}

Allen, F., Babus, A., \& Carletti, E. (2009). Financial crises: Theory and evidence. Annual Review of Financial Economics, 1(1), 97-116. http://http://dx.doi.org/10.2139/ssrn.1422715

Ashcraft, A. B. (2004). Are bank holding companies a source of strength to their banking subsidiaries? Federal Reserve Bank of New York. http://http://dx.doi.org/10.1111/j.1538-4616.2008.00113.x

Balin, B. J. (2008). Basel I, Basel II, and Emerging Markets: A Nontechnical Analysis. The John Hopkins University School of Advanced International Studies. http://dx.doi.org/10.2139/ssrn.1477712

Berger, A. N., \& Bouwman, C. H. S. (2010). How Does Capital Affect Bank Performance During Financial Crises? Wharton Financial Institutions Center WP, pp. 11-22. http://dx.doi.org/10.1016/j.jfineco.2013.02.008

Berger, A. N., Herring, R. J., \& Szegö, G. P. (1995). The role of capital in financial institutions. Journal of Banking \& Finance, 19(3-4), 393-430. http://dx.doi.org/10.1016/0378-4266(95)00002-X

Berger, A. N., Klapper, L. F., \& Turk-Ariss, R. (2009). Bank competition and financial stability. Journal of Financial Services Research, 35(2), 99-118.

Bertrand, R. (2001). Capital requirements and bank behaviour: Empirical evidence for Switzerland. Journal of Banking \&Ffinance, 25, 789-805. http://dx.doi.org/10.1016/S0378-4266(00)00105-9

Bhattacharya, S., Boot, A. W. A., \& Thakor, A. V. (1998). The economics of bank regulation. Journal of Money, Credit and Banking, 745-770. http://dx.doi.org/10.2307/2601127

Buser, S. A., Chen, A. H., \& Kane, E. J. (1981). Federal deposit insurance, regulatory policy, and optimal bank capital. Journal of Finance, 51-60. http://dx.doi.org/10.1111/j.1540-6261.1981.tb03534.x

Dewatripont, M., \& Tirole, J. (1994). The prudential regulation of banks.

Diamond, D. W., \& Rajan, R. (2000). Banks, short term debt and financial crises: Theory, policy implications and applications. National Bureau of Economic Research Cambridge, Mass., USA. http://dx.doi.org/10.1016/S0167-2231(01)00039-2

Flannery, M. J. (2007). Supervising bank safety and soundness: Some open issues. Economic Review-Federal Reserve Bank of Atlanta, 92(1/2), 83.

Flannery, M. J., \& Hankins, K. W. (2007). A theory of capital structure adjustment speed (Unpublished Manuscript). University of Florida.

Furlong, F. T., \& Keeley, M. C. (1989). Capital regulation and bank risk-taking: A note. Journal of Banking \& Finance, 13(6), 883-891. http://dx.doi.org/10.1016/0378-4266(89)90008-3

Goodhart, C. A. E. (2008). The regulatory response to the financial crisis. Journal of Financial Stability, 4(4), 351-358. http://dx.doi.org/10.1016/j.jfs.2008.09.005

Gropp, R., \& Heider, F. (2010). The Determinants of Bank Capital Structure. Review of Finance, 14(4), 587.

Gujarati, D. N. (2003). Basic Econometrics. Boston: McGraw Hill. http://dx.doi.org/10.1093/rof/rfp030

Hackbarth, D., Mathews, R., \& Robinson, D. (2011). Innovation, Capital Structure, and the Boundaries of the Firm.

Hellmann, T. F., Murdock, K. C., \& Stiglitz, J. E. (2000). Liberalization, moral hazard in banking, and prudential regulation: Are capital requirements enough? American Economic Review, 147-165.

Hsiao, C. (2003). Analysis of panel data. Cambridge Univ Pr.

Jackson, P., \& Furfine, C. (1999). Capital requirements and bank behaviour: The impact of the Basle Accord. Bank for International Settlements.

Jacques, K., \& Nigro, P. (1997). Risk-based capital, portfolio risk, and bank capital: A simultaneous equations $\begin{array}{lllll}\text { approach. Journal of Economics and } & \text { Business, 49(6), 533-547. }\end{array}$ http://dx.doi.org/10.1016/S0148-6195(97)00038-6

Kareken, J. H., \& Wallace, N. (1978). Deposit insurance and bank regulation: A partial-equilibrium exposition. 
Journal of Business, 413-438. http://www.jstor.org/stable/2352275

Kim, D., \& Santomero, A. M. (1988). Risk in banking and capital regulation. The Journal of Finance, 43(5), 1219-1233. http://dx.doi.org/10.1111/j.1540-6261.1988.tb03966.x

Mehran, H., \& Thakor, A. (2011). Bank capital and value in the cross-section. Review of Financial Studies, 24(4), 1019. http://dx.doi.org/10.1093/rfs/hhq022

Merton, R. K. (1968). Social theory and social structure. Free Pr.

Rime, B. (2001). Capital requirements and bank behaviour: Empirical evidence for Switzerland. Journal of Banking \& Finance, 25(4), 789-805. http://dx.doi.org/10.1016/S0378-4266(00)00105-9

Shim, J. (2010). Capital-based regulation, portfolio risk and capital determination: Empirical evidence from the US property-liability insurers. Journal of Banking \& Finance, 34(10), 2450-2461. http://dx.doi.org/10.1016/j.jbankfin.2010.04.003

Shrieves, R. E., \& Dahl, D. (1992). The relationship between risk and capital in commercial banks. Journal of Banking \& Finance, 16(2), 439-457. http://dx.doi.org/10.1016/0378-4266(92)90024-T

\section{Copyrights}

Copyright for this article is retained by the author(s), with first publication rights granted to the journal.

This is an open-access article distributed under the terms and conditions of the Creative Commons Attribution license (http://creativecommons.org/licenses/by/3.0/). 